\title{
MIDNIGHT IN THE CATHEDRAL OF TIME
}

\author{
Dream sequence.
}

\section{BY PRESTON GRASSMANN}

W alking through the crowded streets in Canvas Town, I pass a booth that claims to sell the god-ware of angelic systems; codes that open gateways to palaces of corporate data. I pass the aisles of snake-oil salesmen, hawking the latest nanotech cures for assorted ailments, from back pain to cancer. Through the aisles, the gold and silver relics of archaic religions are nestled among the silicon and plastic wafers of data-chips.

The man I'm searching for sits in the corner of the tent and looks up slowly. His eyes catch a glint of light from mechanically modified plasmaeels that swim in a tank at the entrance of his shop. As I enter, he smiles and hunches slowly forward, a conspirator waiting to whisper a secret. Towers fall and cathedrals break apart across his chest, streets narrow across his ribs to make room for buildings; his skin altering in the movement.

"You finally made it back," he says, his lips turning a mountain ravine into a cave of broken stalactites. $\mathrm{He}$ watches me with grey-green eyes.

"What made you think I would?" I ask, watching as two eels collide in a surge of blue light, plasma flickering around their bodies. A few people stand at the entrance, placing their hands on the surface of the tank to watch the storm surge around their fingers.

"Lucid dreamers always return."

I begin to see the illustrations spreading outwards from his body, an artist's outline that turns into solid shapes. The mountain across his cheekbones begins to melt, spreading down his chest, colours pouring across his skin like watercolours.

The DJ stays where he is, unmoving, as if waiting for me to act.

"One reading is all it takes for some," he says, reaching out for the data-chip. I place it in his open palm. "Before they become..."

"Dream junkies?"

He nods slowly.

A crowd begins to gather outside the shop.

$\rightarrow$ NATURE.COM

Follow Futures:

y @NatureFutures

$f$ go.nature.com/mtoodm
He replays the images of dreams from previous customers. Another image forms across his chest; bright green palms swaying among a village of burning homes, spires of smoke rising across his shoulders like wings.

The data-chips were dreams rendered into code. There were only a few technicians who understood how such data could be used, and even fewer who could render them into

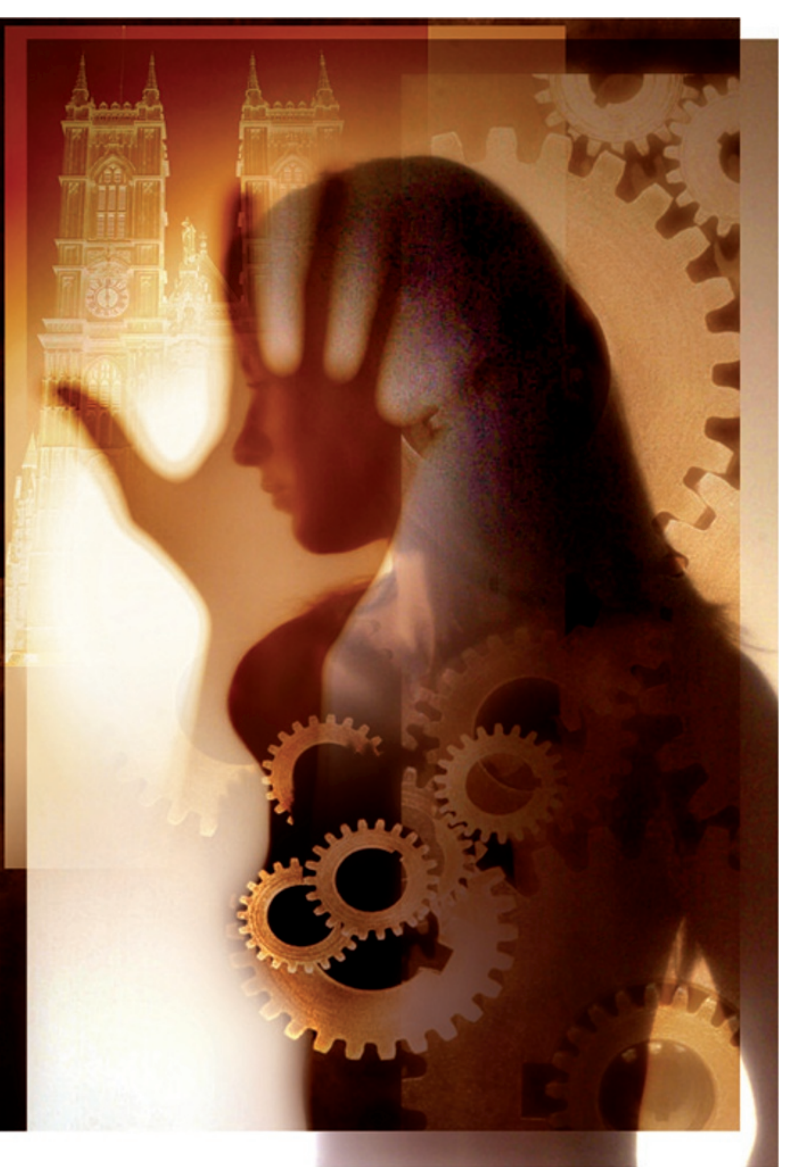

coherent forms. This man had chosen to turn it into an art. As he read the data-card, the images would be distilled and remixed, projected on his skin in high resolution.

"Shall we keep this private?" he asks, the pictures on his skin shifting too quickly to be seen.

"Yes."

He rises for a moment to move the audience away and pulls a low Japanese panelscreen across the entrance.

"There are more details here than before," he says, as the shadows across his chest begin to resolve, her face becoming clearer, chiaroscuro lines opening into the shadowed hollows of her eyes, the twist of a red mouth, the familiar angles of her cheeks. She stands at the entrance. "It's midnight...," she says, the voice of the DJ altering to let hers come through.

She is wraith-thin and dressed in a silk robe and she retreats back into the cathedral, moving as if part of some clockwork mechanism. Through a sequence of images, I watch myself enter, searching for her through the aisles. Everything inside is turning with rusted clockwork parts and the corroded mandalas of half-broken gears. In the pews, worshippers hold the remains of broken clocks. The springs and cogs are spread across their open palms like hymnals.

"Horo-shippers," the DJ says softly, smiling. "Clever."

And then I find her, staring up at the altar. She doesn't turn away as I approach. Even as I put my hand on her shoulder, she remains still. All at once, everything stops. The DJ is motionless, his smile fading as the images of the gears stop turning and the parts fall out of the worshippers' hands and clatter on the floor. And then there is only stillness inside and I run to the altar and beat my fists against its walls, striking out against the mechanism. "Not yet," I say, my own voice echoing around me. "Come back."

That's when the face of the man begins to shift and flow, and she is there, the slope of her cheeks, the curve of her mouth, the soft line of her eyebrows, eyes rendered in the space of eyelids; the same bright, piercing blue-green that I remember so well. And then her body forms, shaping itself across the terrain of his arms, his chest, flowing down the length of his body, until the DJ's skin is only a faint outline around hers. For a moment I can still see the gears, as if she has become the cathedral, the movements of time, her heart the mechanism that makes the gears turn, but they soon fade until it is only her body reaching out for mine.

"Come," she says, and though I know this can't be part of my recorded dream, that it's only an offering, I will hold her for as long as I can.

Preston Grassmann is co-author of The Floating World, a collaboration with K. J. Bishop. He currently lives in Japan, surrounded by a growing collection of drawings, paintings and unreliable maps of the Tokyo underground. 